\title{
DOES THE RISE OF ISLAMIC CONSERVATISM THREATEN INDONESIAN DEMOCRACY?
}

\section{Panji Tanashur}

The Australian National University

Panjitanashur@gmail.com

\begin{abstract}
Some moderate Islamic scholars who criticized the action of defending Islam reaped ridicule and bullies from the demonstrators. On the other hand, they continue to appraise Rizieq Syihab as a central figure in the Islamic defense action. The descriptions above illustrate that the dominance of Islamic radicalism in Indonesia, which I consider a threat to the progress of Indonesian Democracy. This article will explore more about the issues of Islam, politics and democracy in Indonesia.
\end{abstract}

Key word: Aksi Bela Islam, Rizieq Syihab, Demokrasi

\section{A. The Image of Islam and Democracy in Indonesia}

Indonesia's success in changing the authoritarian regime to the democratic political system is an essential phase of Indonesia's history. The achievement creates a complementary view from the world community, especially countries with a democratic political system. Even though Indonesia is categorized as the largest Muslim population, Indonesia has peacefully compromised all the principles that lie in the five principles, called Pancasila. Once again, the world community assigned Indonesia a prominent example of an effective combination of Democracy and Islam.

Hefner (2001) stated that the optimistic future of Indonesian Democracy depends on the two most prominent Islamic organizations, called Nahdatul Ulama (NU) and Muhammadiyah. These two organizations play significant roles in the development of Democracy and Indonesia as the antidotes of any radical Islamic ideology that emerges in Indonesia. Besides, their role in democratic electoral, law enforcement, issuing fatwas, establishing educational facilities, health, and social brings significant developments in modern Indonesia. The humanity movements can also be categorized as a generous contribution to the Indonesian Democratic system's development.

After the above Hefner's optimism with Islam in Indonesia, the relationship between Islam and Democracy has undergone various changes. For example, Martin Van Bruinessen noted a conservative turn, which called a shift of the face of Indonesian Islam in a conservative direction (Bruinessen: 2013). Something has changed Islam in Indonesia from friendly tolerance Islam to liberal or conservative Islam. It can be clearly seen that the threat from the extremist has been noticed since 
some terrorism attack Indonesia for example, the Bali bombing in 2002, MuslimChristian conflict in Ambon and Halmahera, and so on. But the focus of this essay is the growing Islamist deed in some moderate Islamic organizations in Indonesia. According to Burhani (2006), the rise of conservatism is noticed in the body of Muhammadiyah.

This phenomenon has happened since some organization's central figures are changed, such as M. Amien Rais and Ahmad Syafii Maarif. He emphasized that the growing influence of Wahabi's ideology within the organization is noticed since the great scholar from Padang, Haji Rasul plays a significant role in forming the Muhammadiyah orientation. Haji Rasul was claimed as one of the prominent intellectuals of religious puritanism and revivalism in Minangkabau (Alfian: 1989). As a result, the color of Muhammadiyah in Minangkabau and Java is different, depicting that the Minangkabau Muhammadiyah clearly separates religion and local culture. Another product of the Islamist orientation in the body of Muhammadiyah is the emergence of Majelis Tarjih that is categorized as an assembly with Shariah orientation.

Besides, innovation and progressive thinker's potential tend to be marginalized (Bruinessen: 2013). This shows the acts of conservative Islam, which is categorized as pure Islam or anti-innovation. Furthermore, Islamic leaders and political parties' role in changing the Indonesian political constellation cannot be doubted. From the local to the national level, political contestants who carry Islamic aspirations are increasingly significant regardless of their party affiliations. These politicians then frequently use a religious identity to attract sympathizers throughout the country. These are the preliminary view on the shift of the harmonization between Islam and Democracy in Indonesia.

\section{B. Islamist Movements Against Democracy And Its Prevalent Narratives.}

As a material for observation, Ahok's defeat in the 2017 Jakarta Gubernatorial election has clarified the above phenomenon. Prior to the election, hundreds of thousands of mass-bound demonstrations demanding for Ahok, a Chinese-Indonesian Christian, to be jailed and tried on charges of blasphemy. Along with this protest, preachers are continuously informing people both in the mosques or through social media that choosing non-Muslim leaders is sinful.

Meanwhile, they agreed to issue several policies that accommodate Islamists' interests in the policymaking room, such as a family resilience bill. Sharia laws are increasingly implemented (e.g., Bank Sharia regional) and echoing. At the legislative level, some conservative tone of bills is starting to get support from the parliament 
members. Citing a study from Buehler (2013) explains that a number of exclusive public policies only accommodate one group (Islam) and discriminate against nonMuslims. In the 1999-2009 period, there were at least 169 public policies in various regions, provinces, and districts, categorized as Sharia policies.

Liddle and Mujani (2007) state that in a country where the population is predominantly Muslim, effort to make public policies related to Islamic law usually comes from people's representatives from Islamic ideology parties. But the case of Indonesia is different because the domination of Islamic ideology (such as PKS) is not significant compared to the nationalist parties. According to Buehler (2013), what has happened in several regions in Indonesia, is that local legislators from many nationalist parties actually carry out public policies which lead to Islamism.

Meanwhile, among the public figures and artists on television, the idea of "hijrah" is increasingly being flourished and misinterpret, which was not merely changing outfit and appearance (e.g., cingkrang ${ }^{1}$, growing beard, wearing the niqab or long veil). This idea then became a new trend among Indonesian youth. This phenomenon shows the rising Islamic narrative is increasingly prevalent in Indonesia. Concerning the future of the Indonesian democratic system, the proliferation of Islamic narratives and movements might harm Indonesian Democracy.

Seeing this fact, extremists seem to gain the courage and momentum to show their strength and dominance in changing the political constellation in Indonesia. It can be interpreted that the defeat of Ahok in the 2017 election resulted from the Aksi Bela Islam mobilized by the extremists. Their further step is to make the ljtima' ulama (Islamic congregation represent millions of Muslims) right before the 2019 presidential elections. On that occasion, they claimed themselves as the representatives of the whole Indonesian Muslims, which was identified as an ambitious claim. This situation might determine Indonesian politics' shape by establishing its formal institution and informal social network.

\section{Radicalism in Ormass and Political parties}

Talking about Indonesian Islamic organizations or ormass might not be far from the two most prominent Islamic organizations called Muhammadiyah and NU. The radical Islamic ideology might treat the influence of the $\mathrm{NU}$ and Muhammadiyah, who are claiming themselves as the democratic supporter. The influence of the ormas is becoming increasingly vital considering the outcomes of politics, which is very much

\footnotetext{
${ }^{1}$ Cingkrang is trousers that hang above the ankles. It is usually associated with the male muslim's style. See also Maarif, Zainul. "Sunni: Makna, Acuan dan Ragam (Sunni: Meaning, Reference and Variety)." (2018).
} 
determined by the local election and the influence of sharia policies. The role includes how the ormas mobilize the people and gain support as an elongate element in informal social mobilization. Since 1998, Islam has become more flourishing nationwide, and following with the expression of devotion has become visible among the public.

This freedom contributes to the emergence of umpteen, radical Islamic organizations. But the proliferation of Islamic organizations in society cannot serve as a mere guarantee of support to the Islamic friendly parties (PKB, PPP, or PKS) ${ }^{2}$ in Indonesian elections. Several experts began to debate the phenomenon that occurred in Indonesia related to the above situation. Some state that Indonesia is a Muslim majority country that adheres to secular Democracy. In all elections also showed that Islamic friendly parties never been outperformed the secular parties. It can be claimed because of "rational" voters (Tanuwidjaja, 2010).

Specifically, the voters will cast their vote based on the figure capabilities rather than party affiliation, and the party programs rather than the religion. On the other side, scholars also believe that the secular parties have actually started to change direction by accommodating Islamist agendas to broaden the constituency's market (Liddle and Mujani, 2007). The above views have made the political constellation of Islam through political parties increasingly blurred. Besides, the figures affiliated with secular parties use Islamist narratives in the campaign process to gain support in the community. It shows that the Islamist agenda was narrated at the political elites and the grassroots level.

This is where Islamic mass organizations' role in vernacularizing the Islamist doctrine, narratives, and agenda through the socio-cultural approach. According to Nasiti (2018), there are several advantages of the ormass that political parties do not have; first is moral authority obtained from the theological doctrine. Then it frames Islam as the ideal political system and identity.

Second, ormass have the organizational ability to penetrate deep into remote villages. The third is that their moral and social base allows them to connect to political elites, either formal or informal institutions within the state, and simultaneously retain popularity. I believe that these advantages also significantly contribute to portraying how Islamic narratives are increasingly prevalent in society. It seems to become

${ }^{2}$ Anies Rasyid, Baswedan. "Political Islam in Indonesia: present and future trajectory." Asian Survey 44.5 (2004): 669-690. 
something normal to hear the idea of khilafah, hijrah, sharia law, seeing niqab, long veil, and Islamic outfit trend.

One of the most famous Islamic movement that is recorded in Indonesian history is the Anti-Ahok movement. Even though people affiliated with the radical Islamist organizations are a minority among the demonstrators, they have mobilized a diverse Indonesian Muslim community. According to Ken Miichi ${ }^{3}$, Anti-ahok, antiChristian, and anti-Chinese made the dhikr-assembly atmosphere in the demonstration process as one of the strategies to gather mass so that imaging was a form of a holy worship agenda.

This strategy succeeded in attracting many participants, especially from dhikr assemblies in Jakarta and surrounding areas. People who study Sufism are also very interested in joint dhikr action. It is not surprising that the uniforms and clothes used in the demonstrations are Muslim prayer clothes. Men wear skullcaps and bring prayer rugs, and women bring mukena (a white cloak worn by Muslim women at prayers). This is a strategy to create a dhikr and worship atmosphere. The religious-political means is expressed narratively, symbolically through the activity during the rally.

Some of the most significant mass contributors from the non-Islamist groups or $\mathrm{NU}$ and Muhammadiyah are the majelis Rasullullah (the prophet assembly) and the majelis taklim (religious study group). Even though the relationship between the Islamists and Sufis is contradictory (Bekkaoui and Laremont, 2011), it is very complex and different in 212 demonstrations. It may be united under Islam identity, regardless of the sub-identity within the body of Islam. It is also essential to understand that the leader of Majelis Rasulullah, in his interview, admit that there was a vast number of demands from his members to join the rally.

Here is one identification of one particular strategy to mobilize the rally. The dhikr atmosphere is one of the many strategies used by the Islamist activists to gather the rally, such as China-Communist ${ }^{45}$, kafir (unbeliever) leader ${ }^{6}$, etc. On the one hand, the "Action to Defend Islam" movement is hopeful of becoming a government stabilizer. Still, on the other side, the manufacture of fear and emotion of the community has been increasingly significant, covering various issues such as economy, politics, and moral

${ }^{3}$ Ken, Miichi. "Urban Sufi and politics in contemporary Indonesia: the role of dhikr associations in the anti-‘Ahok'rallies." South East Asia Research 27.3 (2019): 225-237.

4 "Rumors there Are Already 10 Million Chinese Workers in Indonesia on the Rise, Jokowi Tells Police to Catch Hoax Spreaders," Coconuts, December 23, 2016, https://coconuts.co/jakarta/news/

5 "The Happy Chinese," The Economist, February 2, 2006, http://www.economist.com/node/5476216

6 “Jika Spanduk Dicopot, FPI siap Tempur dengan Satpol PP” [FPI Would Fight Against Satpol PP (Public Order Enforcers) if Banners Put Down], Wartakotalive.com, 24 September 2014, available at https://wartakota.tribunnews.com/2014/09/24/jika-spanduk-dicopot-fpi-siap-tempur-dengan-satpol-pp 
degradation. It leads the community to seek new possible alternatives, contributing to the development of numerous Islamic thoughts, movements, and radical Islamic organizations.

\section{The Radicalism Is Targeting MUI, NU, Muhammadiyah, And Muslim Scholars.}

As with Sunni Islam in Many Islamic countries, Indonesia knows no single authority. In Indonesia, Islamic authority seems very flexible and open for some legal and recognized institutions. In this context, the fatwas can be issued from the Majelis Ulama Indonesia (MUI, Indonesian Ulama) assembly or NU and Muhammadiyah as the two biggest ormass. Religious institutions such as Nahdatul Ulama (NU), Muhammadiyah, have fatwa institutions to guide his people in various matters, while MUI regularly issues several fatwas ${ }^{7}$ through the Fatwa commission.

The existence of various fatwa institutions shows the freedom and pluralism of understanding and interpreting Islam in Indonesia. Their opinion cannot be mutually exclusive or abolish each other among the fatwas. The diversity of fatwa institution opinions is nothing more than legal diversity opinions that allow people to choose which suits them. The usage of nash (manqul) as a parameter of legal fatwa does not merely fit the people's problems but also how the fatwa can serve justice and moral guidance based on the contextual problem they faced. Therefore, even though the fatwa from the manqul $l^{8}$ perspective is right, it does not merely suit the current reality context.

Considering the importance of issuing fatwa in shaping the country, it is deemed necessary to observe MUI as one of the most trusted fatwa sources in Indonesia. Recently, there have been some considerations to involve MUI in the policymaking process within the legislative. There is also an attempt to make the MUI fatwa becomes positive law, leading many people to assume that the MUI fatwa might hold the highest religious authority in Indonesia.

Somehow, based on the study conducted, MUI has slowly changed more towards conservatism (Ichwan: 2005). Looking at the MUI membership, its members consist of Islamic mass organizations. This recruitment process seems problematic since each ormass has the same number of delegations regardless of how big the

\footnotetext{
${ }^{7}$ Fatwa is a legal opinion that issued by the qualified person as a respond to question posted by a person, judge, or government in the Sharia point of view. Later on, the fatwa plays significant roles in advising court on some difficult points of Islamic law as well as a legitimize the government policies. See Brinkley, Messick. "Fatwa: Process and Function." The Oxford Encyclopedia of the Modern Islamic World 2 (1995).

${ }^{8}$ See Darman Fauzan, Dhahir. "Manqul: Communicating the Message of God to The Diverse Islamic Disciples." Al-Qalam 24.2 (2018): 202-211.
} 
ormass is and the same weight as a vote. For example, NU and Muhammadiyah are the most prominent Islamic organizations in Indonesia, but they have an equal number of the delegation with the other small ormass. Even though NU and Muhammadiyah have moderate views, the Islamist fatwas were issued easily because of the same number of votes and delegation as the other Islamist organizations. The $7^{\text {th }}$ MUI national conference was deemed a crucial momentum to strengthen MUI's attitude on the issue of "threatening the purity of Islam." MUI issued 11 fatwas which sparked controversy, as follows:

1. the violation of intellectual property rights is haram (forbidden),

2. Shamanism and forecasting are haram,

3. praying together among religions are bid' ah, which was not taught in Islamic sharia. Muslims are only allowed to accept prayer from Muslim,

4. Muslims are forbidden to marry someone from other religions,

5. inheritance is haram from an unbeliever, except with a will and grant,

6. MUI has the authority issuing Maslahat or good criteria for the public,

7. MUI prohibits a view to equates all religions, secularism, and liberalism,

8. the state must protect private property rights, and there are no rights for the state to confiscate or reduce.

9. Ahmadiyah is not bringing the teaching of Islam; Ahmadiyah followers are apostate.

10. Unlawful women to become priests of prayer as long as there are men who are already aqil-balig (mature physically and mentally),

11. MUI allows the death penalty for the heavy criminal offenses (Rumadi 2012:46).

From the controversial process of membership recruitment and the issued fatwas, it can be noticed that the MUI holds the conservatism agenda. Almost all fatwas issued are of the sharia flavor, which seems to marginalize the minorities. It may become the new nest of conservatism Islam.

Like the MUI, NU, and Muhammadiyah also played an important role in issuing fatwas and appeals to their members through their commissions. Still, the new challenges emerge as a new power outside of the organizations. Rizieq Shihab is a name that has become the new important figure obtained religious authority after the Aksi Bela Islam movement. The fame of Rizieq Shihab is echoing across the country in his initiative to create the National Movement for Fatwa Defenders of the Ulama Council (GNPF-MUI). 
At the same time, the power of the authority of $\mathrm{NU}$ and Muhammadiyah are getting weaker. Compared to some recommendations issued by Said Aqil Siradj, the chairman of PBNU (Nahdatul Ulama National Board), many NU members were ignoring the advice. Siradj prohibited NU members from joining or supporting the Aksi Bela Islam (Action to Defend Islam) III but encountered humiliate ignorance. Secondly, he issued a fatwa stating that Friday prayers on the street highway are forbidden. Once again, the NU members' persistent ignorance around Jakarta clearly showed; several pesantren ${ }^{9}$ in Ciamis and Tasikmalaya actually sent their students to join the rally in Jakarta on foot $^{10}$.

Moreover, many scholars said that many of NU residents joined and supported the rally even though their chief forbid it. What was happened in NU also occurred in Muhammadiyah. A piece of advice from Haedar Nashir, the chairman of PP Muhammadiyah (Muhammadiyan National board), told his members not to join the rally. However, the negligence from Muhammadiyah sympathizers occurred and kept supporting the Aksi Bela Islam.

Interestingly, the influence of Rizieq Syihab simultaneously weakens the power of both NU and Muhammadiyah leaders within their members. Even though NU and Muhammadiyah from decades are viewed as the moderate Islam Indonesia, but in the case of Aksi Bela Islam (Action to Defend Islam) I, II, II, the two organizations seem toothless. It depicts that the other form of Islam has been raised in Indonesia, giving the negative impacts of moderate Islam Indonesia. At the same time, Syihab continued to build his authority and reputation as a representative of all Islamic ummah. It even strengthens another religious authority beyond NU, Muhammadiyah, and MUI in Indonesia, such as FPI.

Apart from the advice from Haedar Nashir and Said Aqil Siradj, who did not being noticed by their followers, some Muslim scholars such as Muhammad Quraish Syihab, Ahmad Mustofa Bisri, and others experienced the same and even more embarrassment. They tried to criticize the Aksi Bela Islam as an excessive response to the Ahok case. Still, people started to humiliate and bully them through social media and praise Rizieq Syihab as the right one to follow. Once again, the shift of religious

\footnotetext{
${ }^{9}$ Pesantren is an Islamic boarding school which consist of mosque, santri (pupils), teaching of classical Islamic text and, spiritual teachers. It aims to deepen the knowledge of Qoran. See also Ronald, Lukens-Bull. A peaceful jihad: Negotiating identity and modernity in Muslim Java. Springer, 2005

10 “Demo 4 November, Massa dari Luar Kota Mulai Berdatangan ke Jakarta”. SINDOnews.com. 2020-10-22. https://metro.sindonews.com/berita/1152260/171/demo-4-november-massa-dari-luar-kotamulai-berdatangan-ke-jakarta
} 
authority has occurred in Indonesia following the role of Rizieq syihab with FPI in mobilizing people against Ahok accused as a blasphemer.

Of course, NU and Muhammadiyah will still become representations of Indonesian Islam for the years to come. However, as Islam tolerant, friendly, and support Democracy, the view of Islam Indonesia is being polluted within the two organizations. FPI is a new rising color of Islam in Indonesia, which was institutionalized for decades. But the biggest threat is the radicalism within the two prominent organizations like NU and Muhammadiyah, which followed by MUI. As a part of the state circle whose function is to issue fatwas, MUI should maintain its independence from Islamic groups' extremist pressures and political-minded. It may lead to a suspicion that the problem of religious life in Indonesia lies not in society but religious elites.

The use of religious authority to politicize particular interest against minority or other religious beliefs often came from religious elites. Since the strong influence of the Islamist far-right groups such as Rizieq Syihab is growing, the Islamist agenda is also continuous.

\section{E. Conclusion}

Based on the above explanation, the rise of Islamist narrative and agenda is found in the political parties categorized as Indonesian secular parties. None of them is an Islamist party, but the Islamist narratives seem prevalent. The role of ormass in vernacularizing seems significant since the Islamist interest was discovered as the policy product and a trend in Indonesian Muslims, especially the millennials. Seeing the proliferation, the political party might compromise with the broader market of the constituency.

Meanwhile, the assumption that NU and Muhammadiyah as the antidotes of Islamic radicalism might not a hundred percent correct since they show a weakening of their influence within their members. It can be seen from the neglect of the fatwas issued, advice, and their prohibitions by both NU and Muhammadiyah member. Besides, the presence of the MUI, which is fully supported by the government in issuing fatwas, has actually created controversy because the fatwa issued was mostly accommodated by the Islamist Agenda. This condition is reinforced by the membership recruitment system as well as applying the equal quota system even some of them are from NU and Muhammadiyah that possess the most significant mass base. The recruitment system certainly makes it easier for extremists to control and dominate the membership of MUI. 
Some moderate Islamic scholars who criticized the action of defending Islam reaped ridicule and bullies from the demonstrators. On the other hand, they continue to appraise Rizieq Syihab as a central figure in the Islamic defense action. The descriptions above illustrate that the dominance of Islamic radicalism in Indonesia, which I consider a threat to the progress of Indonesian Democracy.

\section{References}

Alfian. Muhammadiyah: The Political Behavior of a Muslim Modernist Organisation Under Dutch Colonialism. Gadjah Mada University Press, 1989.

Baswedan, Anies Rasyid. "Political Islam in Indonesia: Present and future trajectory." Asian Survey 44.5 (2004): 669-690.

Bekkaoui, Khalid, Ricardo René Larémont, and Sadik Rddad. "Survey on Moroccan youth: Perception and participation in Sufi orders/evaluation and interpretation." The Journal of the Middle East and Africa 2.1 (2011): 47-63.

Buehler, Michael. "Subnational Islamization through secular parties: Comparing Shari'a politics in two Indonesian provinces." Comparative Politics 46.1 (2013): 63-82.

Burhani, Ahmad Najib. "The ideological shift of Muhammadiyah from cultural into puritanical tendency in 1930s." Jurnal Masyarakat dan Budaya 8.1 (2006): 1-22.

Coconuts. "Rumors there Are Already 10 Million Chinese Workers in Indonesia on the Rise, Jokowi Tells Police to Catch Hoax Spreaders,". December 23, 2016. https://coconuts.co/jakarta/news/.

Dhahir, Darman Fauzan. "Manqul: Communicating the Message of God to the Diverse Islamic Disciples." Al-Qalam 24.2 (2018): 202-211.

Hefner, Robert W., et al. Civil Islam: Islam dan Demokratisasi di Indonesia. Institut Studi Arus Informasi (ISAI), 2001.

Ichwan, Moch Nur. "Ulama, State, and Politics." Islamic Law and Society 12.1 (2005).

Liddle, R. William, and Saiful Mujani. "Leadership, party, and religion: Explaining voting behavior in Indonesia." Comparative Political Studies 40.7 (2007): 832857.

Lukens-Bull, Ronald. "A peaceful jihad: Negotiating identity and modernity in Muslim Java." Springer, 2005

Maarif, Zainul. "Sunni: Makna, Acuan dan Ragam (Sunni: Meaning, Reference, and Variety)." (2018)

Messick, Brinkley. "Fatwa: Process and Function." The Oxford Encyclopedia of the Modern Islamic World 2 (1995).

Miichi, Ken. "Urban Sufi and politics in contemporary Indonesia: the role of dhikr associations in the anti-"Ahok' rallies." southeast Asia Research 27.3 (2019): 225-237.

Nastiti, Aulia, and Sari Ratri. "Emotive Politics: Islamic Organizations and Religious Mobilization in Indonesia." Contemporary Southeast Asia 40.2 (2018): 196-221.

Rumadi. "islam dan otoritas keagamaan." Walisongo: Jurnal Penelitian Sosial Keagamaan 20.1 (2012): 25-54.

SINDOnews.com. "Demo 4 November, Massa dari Luar Kota Mulai Berdatangan ke Jakarta".

Oktober

22 , 
2020. https://metro.sindonews.com/berita/1152260/171/demo-4-novembermassa-dari-luar-kota-mulai-berdatangan-ke-jakarta.

Tanuwidjaja, Sunny. "Political Islam and Islamic parties in Indonesia: critically assessing the evidence of Islam's political decline." Contemporary Southeast Asia (2010): 29-49.

The Economist. "The Happy Chinese." February 2, 2006. http://www.economist.com/node/5476216.

Van Bruinessen, Martin, ed. Contemporary Developments in Indonesian Islam: Explaining the" Conservative Turn." Institute of Southeast Asian Studies, 2013.

Wartakotalive.com. "Jika Spanduk Dicopot, FPI siap Tempur dengan Satpol PP". September 24, 2014. https://wartakota.tribunnews.com/2014/09/24/jikaspanduk-dicopot-fpi-siap-tempur-dengan-satpol-pp 